\title{
Soil wind erosion characterization in south-eastern Spain using traditional methods in front of an innovative type of dust collector**
}

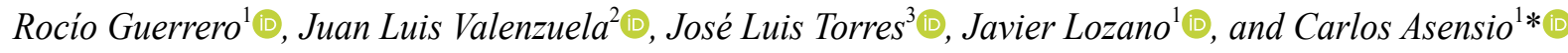 \\ ${ }^{1}$ Department of Agronomy, ${ }^{2}$ Department of Biology and Geology, ${ }^{3}$ Department of Engineering, \\ University of Almeria, Campus University of La Cañada, 04120-Almeria, Spain
}

Received October 14, 2020; accepted December 2, 2020

\begin{abstract}
The movement of soil particles by the wind can be measured using wind tunnels and collectors, or dust traps. We tested both in Southeast Spain in order to compare movement in four types of soil. Our tests were carried out in a well-tilled orchard on an Anthrosol, an unploughed Leptosol and Arenosol, and finally on an olive-cropped Cambisol. We estimated soil loss using a wind tunnel with a built-in laser-scanner, and then compared the results with records from nine vaned masts, each with four big spring number eight collectors at different heights, and the same for another nine masts but with a new type of dust trap known as the multidirectional. The collectors can differentiate between overall loss and particle deposition, which is not detectable on a larger scale in the tunnel. The results from the big spring number eight traps and our wind tunnel showed a high degree of correlation $\left(\mathrm{R}^{2}=0.933\right)$ and an even closer correlation with the multidirectional trap $\left(\mathrm{R}^{2}=0.978\right)$. Moreover, the new multidirectional trap collectors are very efficient and easy to manufacture from thermoplastic filaments with an industrial 3D printer.

Keywords: dust collector, semi-arid environment, tilled soil, unploughed soil, wind tunnel
\end{abstract}

\section{INTRODUCTION}

The wind erosion of soil causes environmental, social and economic problems which have an adverse impact on human health, as well as increasing pollution, crop damage and sand deposition in wells and streams (Novara et al. 2011; Sharifikia 2013). Some regions are more affected than others by wind erosion, this is mainly due to the local

*Corresponding author e-mail: casensio@ual.es

**This study was funded by the Andalusia Regional Government (RNM 3614 grant), and European Union ERDF funds (2015-2018). climate (Borrelli et al., 2016; Weber et al., 2017). A combination of the climate and soil surface conditions affect wind erosion, and thereby the loss of soil productivity. In arid and semiarid areas, where rainfall is scarce and winds are often strong (Burtiev et al., 2013), wind erosion repositions huge amounts of soil, which may cause serious agricultural and environmental problems, such as pollution (Yildiz et al., 2017), a decline in soil water status (Kravchenko et al., 2016) and textural changes, or bury plants before or after emergence. Soil moisture is a very important factor in decreasing soil erodibility, as it raises the threshold wind velocity by increasing soil cohesion (Sharratt et al., 2013). The high temporal and spatial variability in threshold wind velocity has a significant impact on predicting which particles will be transported by the wind (de Oro and Buschiazzo, 2009).

Lozano et al. (2013) and Giménez et al. (2019) analysed the relationships between wind speed, wind erosion, soil type and vegetation in semiarid regions. Wind erosion influences soil drying and nutrient loss (Molchanov et al, 2015), both of which are conditioned by soil surface compaction. Vegetation protects the soil from wind erosion by reducing wind speed, it also reduces soil erodibility, and traps eroded material (Touré et al., 2011; Leenders et al., 2011; Asensio et al., 2015b). Plant cover acts like a windbreak, forcing air to flow through it more slowly and faster

(C) 2020 Institute of Agrophysics, Polish Academy of Sciences 
over the top (Molina-Aiz et al., 2006). The intensity of wind erosion can change the inherent properties of soils and vegetation cover (Li et al., 2004; López et al., 2017).

The movement of blowing particles has been simulated in wind tunnels for many years. These simulation systems have undergone changes over time. There are many models derived from wind tunnel data, but few of them are suitable for use in the field. The prototype from the University of Almeria (Spain) has been patented and is not only applicable to agriculture, but also adds some components specific to soil wind erosion field studies (Giménez et al., 2019), such as a laser-scanner.

Many samplers, collectors or dust traps have also been developed for measuring the material carried by the wind (Goossens et al., 2000), although the Big Spring Number Eight (BSNE; Fryrear, 1986) and the Modified Wilson and Cook (MWAC; Wilson and Cook, 1980) samplers are the most commonly used, according to Zobeck et al. (2003). The choice of collector depends on the type of study to be carried out, the accuracy required and the financial resources available. The models available vary according to size, shape, collection efficiency and type of material to be quantified. In a wind tunnel study, Feras et al. (2008) demonstrated that sediment trap efficiency depends mainly on particle size and wind speed. Collector entrapment efficiency depends on particle size, because those moved by saltation are more easily captured than those in suspension (Shao et al., 1993). Previous studies have shown that the efficiency of BSNE and MWAC varies according to particle size and wind speed (Méndez et al., 2011). Goossens and Buck (2012) found that the BSNE efficiency decreased with particle diameter, as did MWAC efficiency (Feras et al., 2008). In a comparison between MWAC and BSNE efficiency in the field, Mendez et al. (2011) found that effi- ciency increased as particle size decreased and wind speed increased. However, studies were carried out with particles over $10 \mu \mathrm{m}$ in an environment where dry sedimentation was the main deposition mechanism. Vertical sediment flow can be measured by traps placed at different heights (Basaran et al., 2011). Deposition plays an important role in the nutrient cycle of natural ecosystems, as observed in the Sahel (Bielders et al., 2002), where windblown sediment was monitored using BSNE traps in a conventionally managed ploughed area.

Our objectives were to study the material lost due to wind erosion in representative soil types in SE Spain, using different methods and to show the differences between the dust collected as reported by traditional studies and a new technique through an evaluation of the results.

\section{MATERIALS AND METHODS}

The study area is located in Almería Province, Spain (Fig. 1). The climate is semi-arid Mediterranean with a mean annual temperature of $18.5^{\circ} \mathrm{C}$ and rainfall of $243 \mathrm{~mm}$. The dominant geological material is a Miocene sedimentary series. The natural plant communities are isolated native shrubs, but at present, there is also intensive horticultural and tree crop activity. According to the IUSS Working Group WRB (2015), the soils studied are hortic Anthrosol (AT), eutric Leptosol (LP), endosalic Arenosol (AR) and calcaric Cambisol (CM).

Table 1 shows the locations, sampling date, average wind speed and direction, average temperature and relative air humidity at the studied sites. In all cases, there were wind gusts exceeding $14 \mathrm{~m} \mathrm{~s}^{1}$.

Weather records were taken from the automatic meteorological station network of the Institute of Agrarian and Fishing Research and Education of Andalusia (IFAPA)

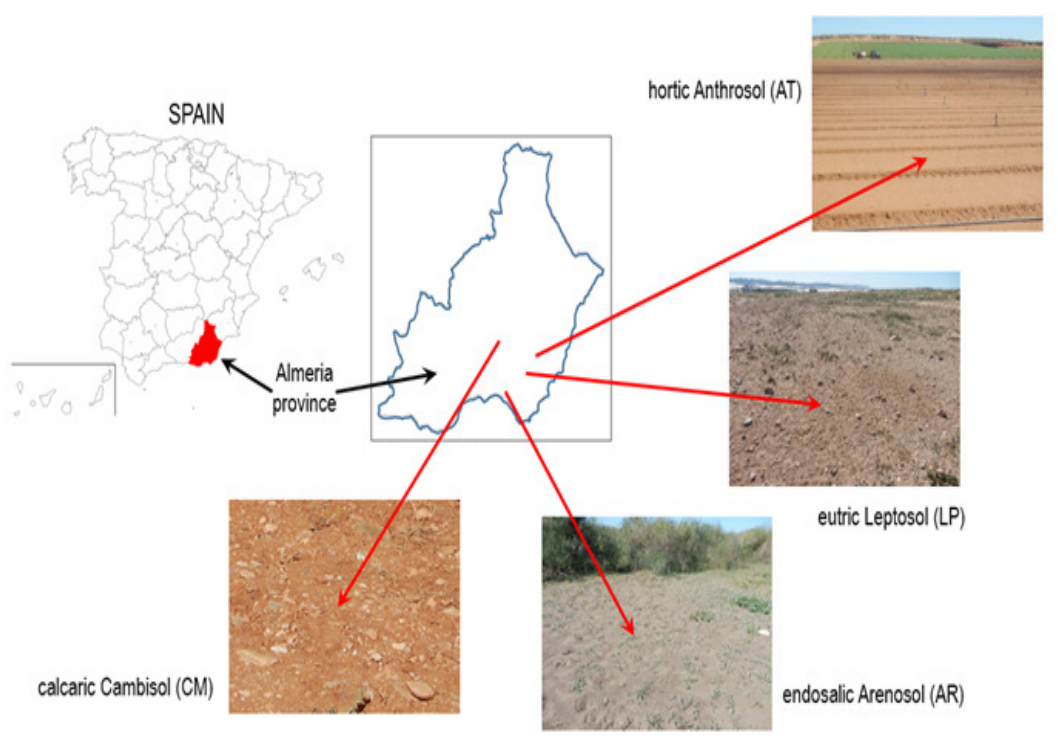

Fig. 1. Location of soils studied. 
Table 1. Coordinates, altitude, sampling date and climatic characteristics of soils studied

\begin{tabular}{|c|c|c|c|c|c|c|c|c|}
\hline \multirow[b]{2}{*}{ Sample } & \multicolumn{3}{|c|}{ Location } & \multirow[b]{2}{*}{$\begin{array}{l}\text { Date } \\
2019\end{array}$} & \multicolumn{4}{|c|}{ Averaged } \\
\hline & \multicolumn{2}{|c|}{ Coordinates } & \multirow{2}{*}{$\begin{array}{c}\begin{array}{c}\text { Altitude } \\
\text { (m) a.s.1. }\end{array} \\
205\end{array}$} & & \multirow{2}{*}{$\begin{array}{c}\begin{array}{c}\text { Wind } \\
\text { speed } \\
\left(\mathrm{m} \mathrm{s}^{-1}\right)\end{array} \\
2.9\end{array}$} & \multirow{2}{*}{$\begin{array}{c}\text { Direction } \\
\left(^{\circ}\right)\end{array}$} & \multirow{2}{*}{$\begin{array}{c}\begin{array}{c}\text { Temperature } \\
\left({ }^{\circ} \mathrm{C}\right)\end{array} \\
20.8\end{array}$} & \multirow{2}{*}{$\begin{array}{c}\begin{array}{c}\text { Relative } \\
\text { humidity } \\
(\%)\end{array} \\
51.0\end{array}$} \\
\hline AT & $36^{\circ} 58^{\prime} 57.94 ” \mathrm{~N}$ & $2^{\circ} 03^{\prime} 40.20^{\prime \prime} \mathrm{W}$ & & $29 / 05$ & & & & \\
\hline LP & $36^{\circ} 55^{\prime} 43.78^{\prime \prime} \mathrm{N}$ & $2^{\circ} 11 ' 19.68^{\prime \prime} \mathrm{W}$ & 174 & $13 / 05$ & 2.7 & 61.5 & 20.6 & 53.7 \\
\hline $\mathrm{AR}$ & $36^{\circ} 50^{\prime} 32.10^{\prime \prime} \mathrm{N}$ & $2^{\circ} 20^{\prime} 30.13^{\prime \prime} \mathrm{W}$ & 8 & $26 / 03$ & 2.9 & 87.7 & 17.6 & 38.4 \\
\hline $\mathrm{CM}$ & $37^{\circ} 06^{\prime} 48.43^{\prime \prime N}$ & $2^{\circ} 18^{\prime} 19.67 ” \mathrm{~W}$ & 579 & $01 / 02$ & 5.4 & 239.4 & 12.3 & 52.9 \\
\hline
\end{tabular}

(http://www.juntadeandalucia.es/agriculturaypesca/ifapa/ $\mathrm{ria} /$ servlet/FrontController), an institution belonging to the Andalusian Regional Government.

Soils were sampled from the upper $5 \mathrm{~cm}$ of the land and four replicates of each sample were assayed. Textural data were found through the use of the Robinson pipette method. Organic carbon content was analysed using the Walkley-Black wet digestion method. Gas volumetry was used to determine the carbonate content. In order to determine bulk density, $100 \mathrm{~cm}^{3}$ cylinders were used so that the sample dry weight could be referred to by cylinder volume.

Wind erosion was monitored in a wind tunnel with a telescopic structure (Fig. 2a). The centre section is equipped with a NextEngine Desktop 3D laser scanner to record changes in the microrelief and later, the volume of the eroded soil (Asensio et al., 2016 and 2019). According to the criteria of Fister and Ries (2009), the wind tunnel
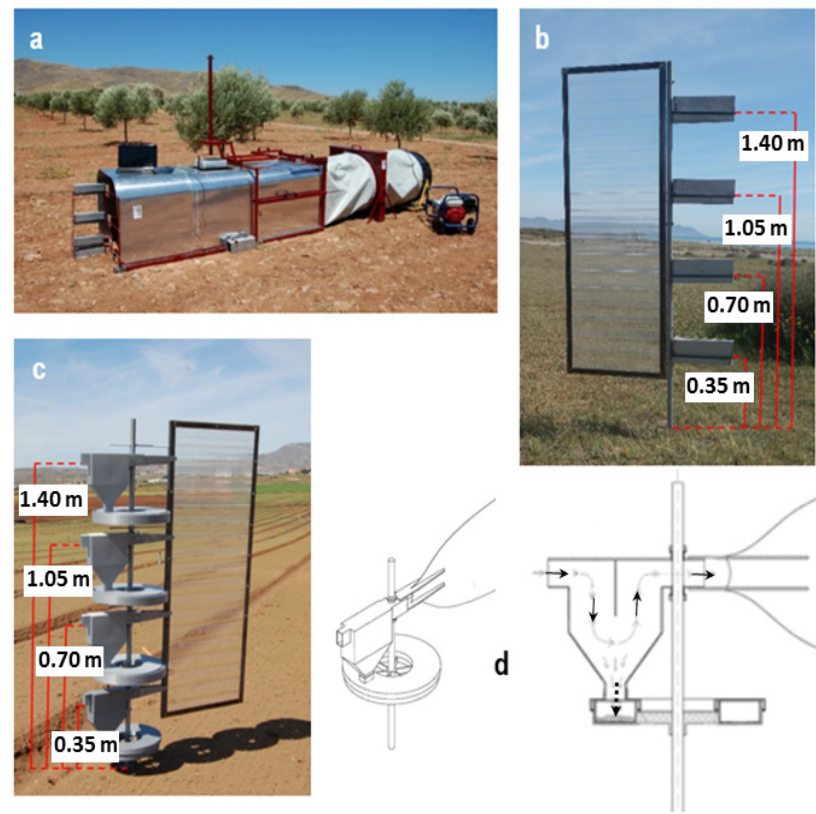

Fig. 2. Wind tunnel on Cambisols (a), mast and wind vane with BSNE collectors on Arenosols (b), mast and vane with MDt collectors on Anthrosols (c), schemes of MDt collectors (d). experiments lasted for ten minutes at $7.2 \mathrm{~m} \mathrm{~s}^{-1}$ wind speed monitored at a height of $70 \mathrm{~cm}$. This wind speed value is the maximum daily average recorded over the last 20 years by agro-climatic stations in our area. The ground was scanned before and after the wind simulation, in each case. These scans provided two point clouds for each plot, from which two digital terrain models (DTMs) were generated. The eroded soil volume was estimated as the difference between DTMs. Thus, the estimate of soil volume lost could be used to estimate the amount of soil lost, by using the soil bulk density (Asensio et al., 2016). This experimental device is suitable for studying the effects of a steady-velocity-wind stream on soil surfaces. This setup is especially favourable for generating comparisons between plots and sites, since air stream speed is a reliably reproducible fixed parameter. Four different plots were chosen for every soil type, so that the data collected would reflect the natural variability of the test plots.

We also used BSNE collectors made from galvanized metal (Fryrear, 1986) in our study (Fig. 2b). These collectors have two parts, a lower tray where the sample is collected and another that is attached above it, but with the top and bottom made of 0.3 and 1 mmdiameter mesh, respectively, both trapezoidal in shape. The material enters through a rectangular $2 \mathrm{~cm}$ wide by $5 \mathrm{~cm}$ high aperture below the top mesh. When the stream of air carrying the material enters the collector, the wind speed is reduced by the collector's shape, and as it collides with the opposite surface, the dust falls through the bottom mesh to the collector tray, while the air escapes through the top mesh. The bottom $1 \mathrm{~mm}$ mesh slows the movement of the material deposited, therefore the finest dust is not lost nor is there any additional disaggregation of the collected material. Each collector was placed on a mast with a wind vane attached to it.

Along with the BSNE collectors, we also used our own patented collectors (Asensio et al., 2015a) fabricated using an industrial 3D printer from a thermoplastic filament, ethylene polyterephthalate modified with glycol (PETg, Fig. 2c). PETg is a strong material, which is ideal for objects subjected to mechanical stress, it is hard, flexible and resistant. A diagram of this new collector design, which 
is referred to as a multidirectional trap (MDt), is shown in Fig. 2d. The air which carries the material enters the collector through a $2 \times 5 \mathrm{~cm}$ rectangular opening and a grill inside modifies its movement. The material is deposited in a removable toroidal-shaped structure at the base. Future studies will allow the direction of origin of the captured materials to be determined through the use of north-facing compartments located in the MDt ring-shaped base. Each of these collectors is also attached to a mast with a weather vane (Fig. 2c). BSNE collector efficiency $(\eta)$, which Fryrear et al. (1994) and Goossens et al. (2018) estimated to be $65 \%$, was particularly good for collecting the very fine material. According to Asensio et al. (2015a), MDt collector efficiency (74\%) is highest for fine grain sizes. Each collector experiment lasted for $24 \mathrm{~h}$.

Nine wind vane masts with BSNE and MDt traps were mounted at $0.35,070,1.05$ and $1.40 \mathrm{~m}$ heights, so that their inlets would face the main wind direction at each moment. The rotating masts were spaced $50 \mathrm{~m}$ apart to prevent interference (Fig. 3). Either for BSNE and MDt traps, the period of measurement was $24 \mathrm{~h}$ and later, the accumulated dust was collected and analysed.

As our collectors were placed at different heights on
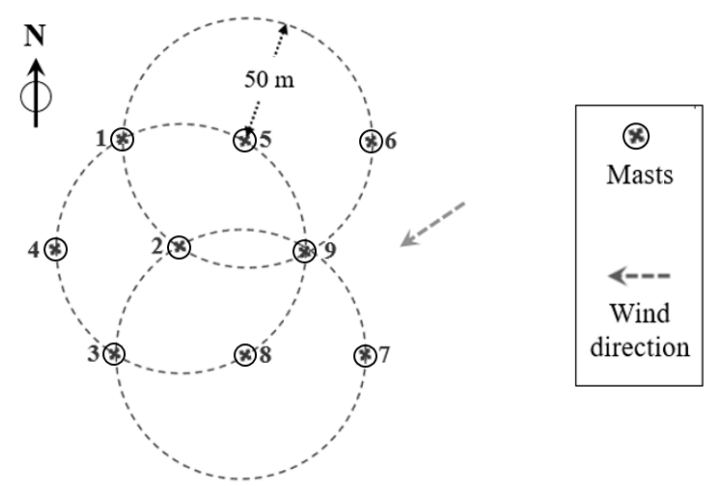

Fig. 3. Example of masts distribution on Leptosols.

the mast starting at $0.35 \mathrm{~m}$, the difference in soil loss rate with distance from the ground could be experimentally measured. This was achieved by a mathematical model predicting the amount of sediment modelled at the surface of the soil surface. The sediment flux $\left(q_{z}, \mathrm{~kg} \mathrm{~m}^{-2}\right)$ at each trap height $(z, \mathrm{~m})$ was obtained using Eq. (1):

$$
q_{z}=\frac{m}{A},
$$

where: $m$ - sediment weight $(\mathrm{kg})$ caught by each collector at a given height, $A$ - inlet area $\left(\mathrm{m}^{2}\right)$ of a collector.

Then, in Eq. (2), the sediment flux was predicted $\left(q_{z . e x p}, \mathrm{~kg} \mathrm{~m}^{-2}\right)$ by an exponential equation for every amount modelled:

$$
q_{z . \exp }=q_{0} e^{-\alpha . z},
$$

where: $q_{0}$ - amount of sediment modelled at $z=0\left(\mathrm{~kg} \mathrm{~m}^{-2}\right)$, $\alpha$-slope factor of the exponential regression equation (m).

Next, the sediment transport rate $\left(Q_{r}, \mathrm{~kg} \mathrm{~m}^{-1}\right)$ was determined by integrating $q_{z . \exp }\left(\mathrm{kg} \mathrm{m}^{-1}\right)$ predicted using Eq. (3):

$$
Q_{r}=\int_{0}^{h} q_{z \cdot \exp } d z,
$$

where: $h$ - maximum particle transportation height $(\mathrm{m})$ recorded. (4):

The total mass transport $\left(Q_{t}, \mathrm{~kg}\right)$ was calculated by Eq.

$$
Q_{t}=\left(\frac{Q_{r}}{\eta}\right) L,
$$

where: $\eta$ - trap efficiency, $L-$ plot width.

The amount of material lost (or deposited) was calculated as the difference in the sediment flux or sediment transport rate between the sampling points located windward and leeward of the prevailing wind direction. Thus, the positive differences indicated gains and the negative ones pointed to a loss of material.

The non-parametric Wilcoxon signed-rank test was performed to determine whether the amount of material captured at the same heights by BSNE and MDt collectors differed. The results of the comparison between the BSNE and MDt collectors are shown in the form of boxplots which indicate the significant ( $\mathrm{p}$-value $<0.05$ ) or insignificant $(p$-value $>0.05)$ differences between the pair of collectors. In all significant cases, the MDt collectors captures more than the BSNE versions.

\section{RESULTS AND DISCUSSION}

Wind erosion is actually an important cause of land degradation worldwide. Therefore, more studies concerning this phenomenon are necessary in order to assist with setting policies and decision-making (Panagos et al., 2012; Borrelli et al., 2016).

Lozano et al. (2013) and Asensio et al. (2015b) suggested that bulk density tends to be reduced by organic enrichment effects, and increased by the accumulation of fine materials, which can affect physical soil crusting.

The mean soil characteristics recorded for Anthrosols, Leptosols, Arenosols and Cambisols in the study area are shown in Table 2. Four replicate samples were taken of each soil type. Surface stoniness is only high for LP and the average gravel content for the different soil types is $6.1 \%$ in AT, $37.3 \%$ in LP, $5.3 \%$ in AR and $47.7 \%$ in CM.

By using a wind tunnel, it was possible to focus on the losses and deposits that occur in a micro plot which the laser scanner is able to detect. The results for the four types of soil blown into the wind tunnel at the same artificially generated wind speed $\left(7.2 \mathrm{~m} \mathrm{~s}^{1}\right)$ are shown in Table 3. 
Table 2. Soils characteristics

\begin{tabular}{|c|c|c|c|c|c|c|c|c|c|c|}
\hline \multirow{2}{*}{ Sample } & $\begin{array}{c}\text { Very C. } \\
\text { Sand }\end{array}$ & $\begin{array}{c}\text { Coarse } \\
\text { Sand }\end{array}$ & $\begin{array}{l}\text { Medium } \\
\text { Sand }\end{array}$ & $\begin{array}{l}\text { Fine } \\
\text { Sand }\end{array}$ & $\begin{array}{c}\text { Very F. } \\
\text { Sand }\end{array}$ & $\begin{array}{c}\text { Coarse } \\
\text { Silt }\end{array}$ & $\begin{array}{l}\text { Fine } \\
\text { Silt }\end{array}$ & Clay & O.C. & $\mathrm{CO}_{3}=$ \\
\hline & \multicolumn{10}{|c|}{$(\%)$} \\
\hline AT & $5.8 \pm 0.4$ & $11.1 \pm 0.9$ & $22.6 \pm 2.4$ & $31.2 \pm 2.6$ & $20.0 \pm 1.9$ & $0.4 \pm 0.2$ & $2.2 \pm 0.7$ & $6.7 \pm 0.9$ & $1.70 \pm 0.21$ & $23 \pm 3$ \\
\hline LP & $15.1 \pm 1.5$ & $14.9 \pm 1.2$ & $22.4 \pm 2.7$ & $24.7 \pm 1.7$ & $5.2 \pm 0.3$ & $6.4 \pm 0.7$ & $2.6 \pm 0.5$ & $8.7 \pm 1.2$ & $3.54 \pm 0.47$ & $19 \pm 4$ \\
\hline AR & $0.3 \pm 0.2$ & $6.1 \pm 0.4$ & $48.8 \pm 3.6$ & $38.2 \pm 2.9$ & $2.9 \pm 0.3$ & $0.5 \pm 0.3$ & $0.2 \pm 0.2$ & $3.0 \pm 0.7$ & $1.25 \pm 0.09$ & $0 \pm 0$ \\
\hline $\mathrm{CM}$ & $0.0 \pm 0.2$ & $8.2 \pm 0.6$ & $7.6 \pm 0.5$ & $8.9 \pm 0.7$ & $20.2 \pm 2.3$ & $28.4 \pm 1.8$ & $7.9 \pm 1.1$ & $18.8 \pm 2.0$ & $1.82 \pm 0.18$ & $20 \pm 2$ \\
\hline
\end{tabular}

Data are means \pm standard deviation $(n=4)$.

Table 3. Wind erosion found in the wind tunnel, after four replicates (A to D)

\begin{tabular}{|c|c|c|c|c|c|c|c|}
\hline \multirow{2}{*}{ Sample } & \multicolumn{5}{|c|}{ Lost (Laser scanner) (mm) } & \multirow{2}{*}{$\begin{array}{l}\text { Bulk density } \\
\qquad\left(\mathrm{t} \mathrm{m}^{-3}\right)\end{array}$} & \multirow{2}{*}{$\begin{array}{l}\text { Wind erosion } \\
\text { (Tunnel) } \\
\left(\mathrm{t} \mathrm{ha}^{-1}\right)\end{array}$} \\
\hline & A & B & $\mathrm{C}$ & $\mathrm{D}$ & Average & & \\
\hline AT & 0.87 & 0.96 & 0.82 & 1.02 & 0.92 & 1.24 & 11.41 \\
\hline LP & 0.78 & 0.73 & 0.67 & 0.87 & 0.76 & 1.36 & 10.34 \\
\hline AR & 0.22 & 0.21 & 0.23 & 0.22 & 0.22 & 1.28 & 2.82 \\
\hline $\mathrm{CM}$ & 1.37 & 1.66 & 1.39 & 1.78 & 1.55 & 1.35 & 20.93 \\
\hline
\end{tabular}

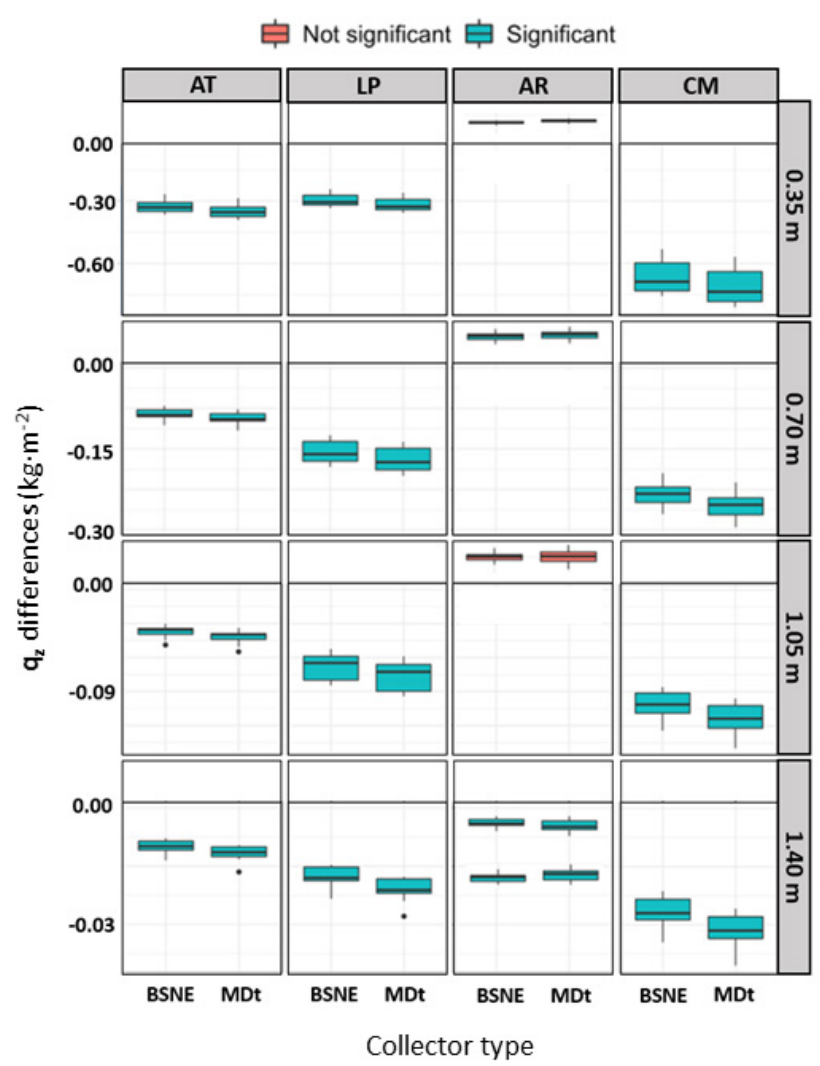

Fig. 4. Comparison of differences in $\mathrm{q}_{\mathrm{z}}$ between BSNE and MDt collectors.

The Anthrosols were sampled from a highly tilled orchard with a low silt and clay content. Measurements took place right after tilling. The Leptosols were sampled from unploughed areas with little protection from the

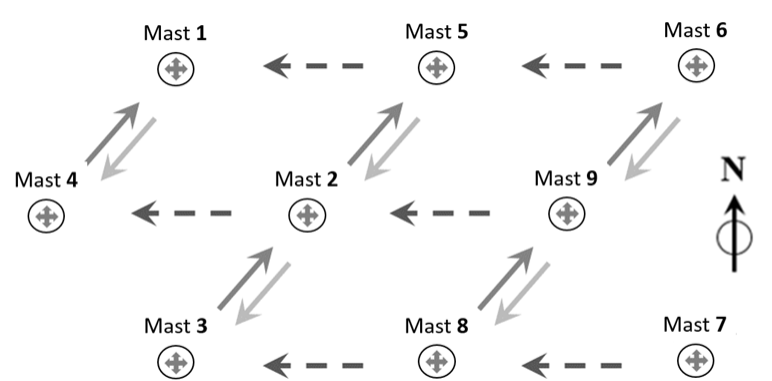

Fig. 5. Masts locations with different kind of arrows showing main wind directions.

direct impact of wind. Arenosols sampled from along the coast had a low very fine sand, silt and clay content where vegetation had an important protective role. Finally, the Cambisols appeared to be crusted in an olive orchard. After tillage, Cambisols are highly erodible by wind, but according to Asensio et al. (2016), with regard to Cambisols, the physical crust tends to recover within 10 to 12 days. For that particular wind tunnel study, the average soil loss was found to be over six times higher in recently tilled Cambisols than for crusted versions of the soil.

The methodology adopted which made use of BSNE and MDt collectors made an in-depth wind erosion study possible. The sediment fluxes on nine masts had both collector types to determine each soil typology at different heights. Figure 4 shows the results of a comparison between the two collector types. The boxplots in red indicate no significant differences ( $p$-value $>0.05$ ) between the pair of collectors. 
Table 4. Mast numbers where values differed on each soil type

\begin{tabular}{|c|c|c|c|c|c|c|c|}
\hline \multirow{2}{*}{$\begin{array}{l}\text { Sample } \\
\text { AT, LP }\end{array}$} & \multirow{2}{*}{$\begin{array}{c}\text { Main wind } \\
\text { direction }\end{array}$} & \multicolumn{6}{|c|}{$\begin{array}{l}\text { Differences in sediment flux captured by masts } \\
\text { (windward - leeward) }\end{array}$} \\
\hline & & M1-M4 & M5-M2 & M6-M9 & M2-M3 & M9-M8 & \\
\hline $\mathrm{AR}$ & from $\mathrm{E}$ & M6-M5 & M9-M2 & M7-M8 & M5-M1 & M2-M4 & M8-M3 \\
\hline $\mathrm{CM}$ & from SW & M4-M1 & M3-M2 & M2-M5 & M8-M9 & M9-M6 & \\
\hline
\end{tabular}

Table 5. Sediment transport rate balance

\begin{tabular}{ccc}
\hline \multirow{2}{*}{ Sample } & \multicolumn{2}{c}{$\mathrm{Q}_{\mathrm{r}}$ balance $\left(\mathrm{kg} \mathrm{m}^{-1}\right)$} \\
\cline { 2 - 3 } & $\mathrm{BSNE}$ & $\mathrm{MDt}$ \\
\hline AT & -0.019 & -0.017 \\
LP & -0.014 & -0.001 \\
AR & 0.001 & 0.005 \\
CM & -0.011 & -0.036 \\
\hline
\end{tabular}

In most cases, the differences in the amount captured are statistically significant, and in all significant cases, MDt captured more material than the BSNE collectors.

According to the data provided by the collectors, the freshly ploughed Cambisols produced the highest emission flux, which is in agreement with other experimental studies (Marzen et al., 2019). Tilling leads to a partial breakdown of crust and clods, thereby generating a comparably high pro- portion of noncohesive substrate of fine fractions which are the most easily erodible by wind. An organic matter content which is not particularly high and the mechanical reduction of aggregate sizes through tilling decreases aggregate stability and further increases the amount of wind-erodible sediment on the surface, particularly under dry soil conditions. This situation is aggravated by long droughts. Since wind erosion leads to a sorting of the soil material predominantly involving the gradual removal of the finest grain sizes, silt and clay, including a high proportion of soil nutrients (Katra et al., 2016), it is a severe threat to soil management.

As the main wind direction over each soil type was different (Fig. 5), a dataset composed of the differences between the sampling points located windward and leeward relative to the prevailing wind direction (Table 4). Thus, positive differences indicated gains and negative ones pointed to a loss of material.

As a result, the estimated sediment transport rate balance for the nine masts with both collector types for each soil typology are shown in Table 5. This clearly indicated

Table 6. Total mass transport $\left(Q_{t}\right)$

\begin{tabular}{|c|c|c|c|c|c|c|c|c|c|c|}
\hline \multirow{2}{*}{ Sample } & \multicolumn{10}{|c|}{ Vaned mast } \\
\hline & 1 & 2 & 3 & 4 & 5 & 6 & 7 & 8 & 9 & Average \\
\hline \multicolumn{11}{|c|}{$Q_{t}(\mathrm{BSNE})(\mathrm{kg})$} \\
\hline AT & 15.54 & 18.45 & 19.73 & 17.80 & 17.49 & 17.20 & 20.58 & 19.86 & 18.51 & 18.35 \\
\hline LP & 20.83 & 24.82 & 26.85 & 24.26 & 28.62 & 23.24 & 27.73 & 26.81 & 20.49 & 24.85 \\
\hline $\mathrm{AR}$ & 7.71 & 8.262 & 8.83 & 7.615 & 7.573 & 8.430 & 8.002 & 9.019 & 8.142 & 8.175 \\
\hline $\mathrm{CM}$ & 49.43 & 43.59 & 39.14 & 55.02 & 46.57 & 52.93 & 42.43 & 50.72 & 51.90 & 47.97 \\
\hline \multicolumn{11}{|c|}{$Q_{t}(\mathrm{MDt})(\mathrm{kg})$} \\
\hline AT & 21.47 & 20.02 & 22.77 & 22.75 & 19.94 & 18.30 & 23.41 & 19.97 & 17.99 & 20.74 \\
\hline LP & 22.44 & 26.78 & 19.38 & 25.80 & 19.08 & 24.97 & 24.13 & 21.79 & 25.03 & 23.27 \\
\hline $\mathrm{AR}$ & 7.404 & 7.109 & 6.195 & 7.437 & 7.746 & 8.247 & 6.5511 & 7.890 & 8.164 & 7.416 \\
\hline $\mathrm{CM}$ & 44.86 & 40.88 & 37.59 & 53.24 & 49.19 & 51.25 & 38.98 & 42.33 & 50.36 & 45.41 \\
\hline
\end{tabular}


a deposition on Arenosols compared to a loss for the rest of the soils tested. Finally, the total mass transport results are shown in Table 6.

After evaluating sediment transport rates and determining their balance, the Arenosols data indicated that with regard to these soils, material was deposited rather than lost. Data from wind tunnel evaluation showed low Arenosols loss, as this device is a closed structure and cannot detect windward deposition. However, in front of it, the wind tunnel rapidly provided accurate replicable data, mainly concerning soil wind erosion. In addition, a comparison of total mass transport for each soil type from the collectors and wind erosion as reported by the wind tunnel tests showed a high degree of linear correlation $\left(\mathrm{R}^{2}=0.933\right.$ for BSNE-Tunnel data and $\mathrm{R}^{2}=0.978$ for MDt-Tunnel data).

\section{CONCLUSIONS}

1. A wind tunnel is a closed device in which there is no entry of windward deposits. It is mainly used to evaluate the wind erodibility of the soil, more than overall erosion, although the results produced maintain a very close correlation with the data from the particle collectors, showing a higher loss for Cambisols and a lower one for Arenosols.

2. The tunnel provides much faster results. However, with the collectors, the general loss or deposition of particles can be determined, and this is not detectable on a larger scale by the tunnel results.

3. On the other hand, the new multidirectional trap collectors are very efficient and easily manufactured by an industrial 3D printer from thermoplastic filaments, it is therefore a promising technology, which must be subjected to continued testing.

\section{ACKNOWLEDGEMENT}

The authors are grateful to Deborah Fuldauer for the English language revision.

Conflict of interest: The authors declare no conflict of interest.

\section{REFERENCES}

Asensio C., López J., and Lozano F.J., 2015a. Multidirectional collector of particles carried by the wind. Spanish office of the patents and brand. Ref. ES2470090 B1.

Asensio C., Lozano F.J., Ortega E., and Kikvidze Z., 2015 b. Study on the effectiveness of an agricultural technique based on aeoliandeposition, in a semiarid environment. Environ. Eng. Manag. J., 14: 1143-1150. https://doi. org/10.30638/eemj.2015.125

Asensio C., Lozano F.J., Gallardo P., and Giménez A., 2016. Soil wind erosion in ecological olive trees in the Tabernas desert (Southeastern Spain): a wind tunnel experiment. Solid Earth, 7: 1233-1242.

https://doi.org/10.5194/se-7-1233-2016
Asensio C., Weber J., Lozano F.J., and Mielnik L., 2019. Laserscanner use into a wind tunnel to quantify soil erosion. Int. Agrophys., 33: 227-232. https://doi.org/10.31545/intagr/109424

Basaran M., Erpul G., Uzun O., and Gabriels D., 2011. Comparative efficiency testing for a newly designed cyclone type sediment trap for wind erosion measurements. Geomorphology, 130: 343-351. https://doi.org/10.1016/j. geomorph.2011.04.016

Bielders C.L., Rajot J.L., and Amadou M., 2002. Transport of soil and nutrients by wind in bush fallow land and traditionally managed cultivated fields in the Sahel. Geoderma, 109: 19-39. https://doi.org/10.1016/s0016-7061(02)00138-6

Borrelli P., Panagos P., Ballabio C., Lugato E., Weynantgs M., and Montanarella L., 2016. Towards a Pan-European assessment of land susceptibility to wind erosion. Land. Degrad. Dev., 27: 1093-1105. https://doi.org/10.1002/ ldr. 2318

Burtiev R., Greenwell F., and Kolivenko V., 2013. Time series analysis of wind speed and temperatura in Tiraspol, Moldova. Environ. Eng. Manag. J., 12: 23-33. https://doi. org/10.30638/eemj.2013.004

De Oro L.A. And Buschiazzo D.E., 2009. Threshold wind velocity as an index of soil susceptibility to wind erosion under variable climatic conditions. Land. Degrad. Dev., 20: 14-21. https://doi.org/10.1002/ldr.863

Feras Y., Erpul G., Bogman P., Cornelis W.M., and Gabriels D., 2008. Determination of efficiency of Vasaline slide and Wilson and Cook sediment traps by wind tunnel experiments. Environ. Geology, 55: 741-757. https://doi.org/10.1007/s00254-007-1027-9

Fister W. and Ries J.B., 2009. Wind erosion in the central Ebro basin under changing land use management. Field experiments with a portable wind tunnel. J. Arid Environ., 73 (11): 996-1004.

https://doi.org/10.1016/j.jaridenv.2009.05.006

Fryrear D.W., 1986. A field dust sampler. J. Soil Water Conserv., 41: 117-120.

Fryrear D.W., Krammes C.A., Williamson D.L., and Zobeck T.M., 1994. Computing the wind erodible fraction of soils. J. Soil Water Conser., 49: 183-188.

Giménez A., Lozano F.J., Torres J.A., and Asensio C., 2019. Automated system for soil wind erosion studies. Comput. Electron. Agr., 164: 104889. https://doi.org/10.1016/j. compag.2019.104889

Goossens D. and Buck B.J., 2012. Can BSNE (Big Spring Number Eight) samplers be used to measure PM10, respirable dust, PM2.5 and PM1.0? Aeolian Research, 5: 43-49. https://doi.org/10.1016/j.aeolia.2012.03.002

Goossens D., Nolet C., Etyemezian V., Duarte-Campos L., Bakker G., and Riksen M., 2018. Field testing, comparison, and discussion of five aeolian sand transport measuring devices operating on different measuring principles. Aeolian Research, 32: 1-13.

https://doi.org/10.1016/j.aeolia.2018.01.001

Goossens D., Offer Z., and London G., 2000. Wind tunnel and field calibration of five aeolian sand traps. Geomorphology, 35: 233-252.

https://doi.org/10.1016/s0169-555x(00)00041-6 
IUSS Working Group WRB, 2015. International soil classification system for naming soils and creating legends for soil maps, World Soil Resources Reports No. 106. Food and Agriculture Organization of the United Nations, Rome.

Katra I., Gross A., Swet N., Tanner S., Krasnov H., and Angert A., 2016. Substantial dust loss of bioavailable phosphorus from agricultural soils. Scientific Reports, 6: 24736. https:// doi.org/10.1038/srep24736

Kravchenko Y.S., Chen Q., Liu X., Herbert S.J., and Zhang X., 2016. Conservation practices and management in Ukrainian mollisols. J. Agric. Sci. Technol., 16: 1455-1466.

Leenders J.K., Sterk G., and Van Boxel J.H., 2011. Modelling windblown sediment transport around single vegetation elements. Earth Surf. Process. Landf., 36: 1218-1229. https://doi.org/10.1002/esp.2147

Li F.R., Zhao L.Y., and Zhang T.H., 2004. Wind erosion and airborne dust deposition in farmland during spring in the Horqin Sandy Land of eastern Inner Mongolia, China. Soil Till. Res., 75: 121-130. https://doi.org/10.1016/j.still.2003.08.001

Lozano F.J., Soriano M., Martínez S., and Asensio C., 2013. The influence of blowing soil trapped by shrubs on fertility in Tabernas district (SE Spain). Land. Degrad. Dev., 24: 575-581. https://doi.org/10.1002/ldr.2186

López A., Valera D.L, Molina-Aiz F.D., Lozano F.J., and Asensio C., 2017. Sonic anemometry and sediment traps to evaluate the effectiveness of windbreaks in preventing wind erosion. Scientia Agricola, 74: 425-435. https://doi. org/10.1590/1678-992x-2016-0148

Marzen M., Iserloh T., Fister W., Seeger M., Rodrigo Comino J., and Ries J.B., 2019. On-site water and wind erosion experiments reveal relative impact on total soil erosion. Geosciences, 9(11): 478. https://doi.org/10.3390/geosciences9110478

Méndez M.J., Funk R., and Buschiazzo D.E., 2011. Field wind erosion measurements with Big Spring Number Eight (BSNE) and Modified Wilson and Cook (MWAC) samplers. Geomorphology, 129(1-2): 43-48. https://doi.org/10.1016/j.geomorph.2011.01.011

Molchanov E.N., Savin I.Yu., Yakovlev A.S., Bulgakov D.S., and Makarov O.A., 2015. National approaches to evaluation of the degree of soil degradation. Eurasian Soil Science, 48: $1268-1277$.

https://doi.org/10.1134/s1064229315110113
Molina-Aiz F.D., Valera D.L., Álvarez A.J., and Madueño A., 2006. A wind tunnel study of airflow through horticultural crops: determination of the drag coefficient. Biosystems Eng., 93: 447-457. https://doi.org/10.1016/j.biosystemseng.2006.01.016

Novara A., Gristina L., Saladino S.S., Santoro A., and Cerdà A., 2011. Soil erosion assessment on tillage and alternative soil managements in a Sicilian vineyard. Soil Till. Res., 117: 140-147. https://doi.org/10.1016/j.still.2011.09.007

Panagos P., Van Liedekerke M., Jones A., and Montanarella L., 2012. European Soil Data Centre: Response

Shao Y., McTainsh G.H., Leys J.F., and Raupach M.R., 1993. Efficiencies of sediments samplers for wind erosion measurement. Australian J. Soil Res., 31: 519-532. https://doi. org/10.1071/sr9930519

Sharifikia M., 2013. Environmental challenges and drought hazard assessment of Hamoun Desert Lake in Sistan region, Iran, based on the time series of satellite imagery. Natural Hazards, 65: 201-217. https://doi.org/10.1007/s11069-012-0353-8

Sharratt B.S., Vaddella V.K., and Feng G., 2013. Threshold friction velocity influenced by wetness of soils within the Columbia Plateau. Aeolian Res., 9: 175-182. https://doi. org/10.1016/j.aeolia.2013.01.002

Touré A.A., Rajot J.L., Garba Z., Marticorena B., Petit C., and Sebag D., 2011. Impact of very low crop residues cover on wind erosion in the Sahel. Catena, 85: 205-214. https://doi.org/10.1016/j.catena.2011.01.002

Weber J., Kocowicz A., Debicka M., and Jamroz E., 2017. Changes in soil morphology of Podzols affected by alkaline fly ash blown out from the dumping site of an electric power plant. J. Soil Sediments, 17: 1852-1861. https://doi. org/10.1007/s11368-016-1599-7

Wilson S.J. and Cook R.U., 1980. Wind erosion. In: Soil Erosion (Eds M.J. Kirkby, R.P.C. Morgan). Wiley, Chichester, 217-251.

Yildiz S., Enç V., Kara M., Tabak Y., and Acet E., 2017. Assessment of the potential risks of airbone microbial contamination in solid recovered fuel plants: A case study in Istanbul. Environ. Eng. Manag. J., 16: 1415-1421. https:// doi.org/10.30638/eemj.2017.154

Zobeck T.M., Sterk G., Funk R., Rajot J.L., Stout J.E., and Van Pelt R.S., 2003. Measurement and data analysis methods for field-scale wind erosion studies and model validation. Earth Surf. Process. Landf., 28: 1163-1188. https://doi.org/10.1002/esp.1033 